\section{Evaluation of Apically Extruded Debris Using Positive and Negative Pressure Irrigation Systems in Association with Different Irrigants}

Marlos Barbosa-Ribeiro ${ }^{1}$, Rodrigo Arruda-Vasconcelos ${ }^{1}$, Fabio L. Fabretti ${ }^{1}$, Emmanuel J. N. L Silva2,3, Gustavo De-Deus ${ }^{3,4}$, Brenda P. F. A. Gomes ${ }^{1}$

This study evaluated the amount of apically extruded debris after chemo-mechanical preparation (CMP) using positive and negative pressure irrigation systems [Conventional irrigation $(\mathrm{Cl})$ and EndoVac (EV)] in association with different irrigants [6\% Sodium Hypochlorite $(\mathrm{NaOCl}), 2 \%$ Chlorhexidine gel + saline solution ( $\mathrm{CHXg}+\mathrm{SS}), 2 \%$ Chlorhexidine solution (CHXs) or Saline solution (SS)]. Eighty mandibular premolars with single root canals were selected and randomly assigned into 8 groups $(n=10)$ according to the irrigation system and the irrigant used during CMP: G1 (EV + NaOCI), G2 (EV + CHXg + SS), G3 (EV $+\mathrm{CHXs}), \mathrm{G} 4(\mathrm{EV}+\mathrm{SS}), \mathrm{G} 5(\mathrm{Cl}+\mathrm{NaOCl}), \mathrm{G} 6(\mathrm{Cl}+\mathrm{CHXg}+\mathrm{SS}), \mathrm{G} 7(\mathrm{Cl}+\mathrm{CHXs})$ and $\mathrm{G} 8(\mathrm{Cl}$ + SS). Reciproc ${ }^{\circledR}$ R25 files (25/.08) were used during the CMP and the extruded debris from each tooth was collected in pre-weighted Eppendorf tubes and dried. The average weight of debris was assessed using a microbalance, and the data were statistically analyzed using ANOVA and the post hoc Tukey's test $(\alpha=0.05)$. All groups were associated with debris extrusion. EV was the irrigation system with less extruded debris $(p<0.05)$. No differences were observed regarding the irrigant when $\mathrm{EV}$ was used. When $\mathrm{Cl}$ was used, $\mathrm{CHXg}+\mathrm{SS}$ were associated with lower debris extrusion $(\mathrm{p}<0.05)$. It was concluded that no irrigation protocol succeeded in preventing debris extrusion. EV resulted in lower levels of debris extrusion than $\mathrm{Cl}$. The use of $\mathrm{CHXg}+\mathrm{SS}$ resulted in lower debris extrusion.

\author{
'Department of Restorative \\ Dentistry, Division of Endodontics, \\ Piracicaba Dental School, State \\ UNICAMP - Universidade Estadual \\ de Campinas, Piracicaba, SP, Brazil \\ ${ }^{2}$ Department of Integrated Clinical \\ Procedures, Division of Endodontics, \\ UERJ - Universidade Estadual do Rio \\ de Janeiro, Rio de Janeiro, RJ, Brazil \\ ${ }^{3}$ Department of Endodontics, \\ School of Dentistry, UNIGRANRIO \\ - Universidade Grande Rio, \\ Rio de Janeiro, RJ, Brazil \\ ${ }^{4}$ Department of Endodontics, UFF \\ - Universidade Federal Fluminense, \\ Rio de Janeiro, RJ, Brazil
}

Correspondence: Brenda P. F. A. Gomes, Avenida Limeira, 901, Bairro Areião, 13414-903 Piracicaba, SP, Brazil. Tel: +55-19-2106-5343. e-mail address: bpgomes@unicamp.br

Key Words: chlorhexidine. debris extrusion. endovac. reciprocating files. sodium hypochlorite.

\section{Introduction}

During chemo-mechanical preparation (CMP), root canal instruments and intracanal irrigants are used for the elimination of pulp tissue, microorganisms, as well as for the removal of debris from the root canal system (1). During the use of endodontic instruments and irrigants, organic and inorganic debris, bacteria and irrigants may extrude to the periradicular tissues (2-4). An important clinical situation resulting from apically extruded debris during endodontic therapy has to do with flare-up, which consists of acute exacerbations of an asymptomatic pulpal and/or periradicular pathologic condition. This condition is not desirable for patients and clinicians, and may happen from $2-3.2 \%$ of the cases (5-7).

Currently, different irrigation substances and delivery systems have been used to improve the root canal system disinfection. Conventional irrigation (Cl) uses various needle types adapted to a disposable plastic syringe associated with apical positive pressure and is widely accepted (8). However, its safety has been questioned since positive pressure used to introduce the irrigant into the canal may cause extrusion of the solution to periradicular tissues, resulting in severe tissue damage and postoperative pain (9). EndoVac system (EV) (SybronEndo, Orange, CA, USA) comprises an alternative irrigation regimen developed with the aim of reducing the risk of extruding the irrigation solution into the periradicular tissues due to negative pressure along the working length (10). The EV can be regarded as safe when used during root canal treatment, which is confirmed by studies showing low extrusion during EV irrigation (10-12).

Sodium hypochlorite $(\mathrm{NaOCl})$ is widely used as the main irrigant during endodontic therapy (13). However, chlorhexidine (CHX) has been suggested as an alternative to $\mathrm{NaOCl}$ due to its properties: a wide range of antimicrobial activity, substantivity, lower cytotoxicity than $\mathrm{NaOCl}$, lubricating properties and efficient clinical performance (14). Furthermore, gel-based CHX shows rheological action, which keeps the debris in suspension (14). This property might be associated with a reduction in the risk of debris extrusion and consequently the incidence of flare-ups.

Although most studies associate the extrusion of debris caused by different preparation techniques and by the instruments used $(2,3,15-18)$ the literature is scarce on the correlation between different irrigation techniques and irrigant substances. Therefore, the current ex vivo study was designed to evaluate the amount of apically extruded debris after CMP of root canals with two different irrigation techniques ( $\mathrm{EV}$ and $\mathrm{Cl})$ in association with four different root canal irrigants [(6\% $\mathrm{NaOCl}(\mathrm{NaOCl}), 2 \% \mathrm{CHX}$ gel ( $\mathrm{CHXg})$ + saline solution (SS), 2\% CHX solution (CHXs) and SS]. 
The null hypothesis tested was: there are no significant differences on the amount of extruded debris amongst the irrigation techniques and root canal irrigants.

\section{Material and Methods}

The method for assessment of apically extruded debris was adapted from De-Deus et al. (19).

\section{Sample Selection}

This study was revised and approved by the local ethics committee. Eighty freshly extracted human premolars with similar root length were selected. The inclusion criteria were single-rooted teeth with one root canal and one apical foramen with a mature apex radiographically confirmed. Soft tissue remnants and calculus on the external root surface were removed mechanically. Then, the teeth were disinfected in $0.5 \%$ chloramine $\mathrm{T}$, stored in distilled water at $4^{\circ} \mathrm{C}$ and used within 6 months after extraction. To standardize the root canal curvature, digital radiographs of each tooth were taken and the angle of curvature of each canal was measured using an image analysis program (AxioVision 4.5; Carl Zeiss Vision, Hallbergmoos, Germany). The angle of curvature was considered to initiate at the coronal aspect of the apical third of the canal (20) and only those teeth with canal curvature $<10^{\circ}$ and an initial apical size equivalent to a size $15 \mathrm{~K}$-file (Dentsply Maillefer, Ballaigues, Switzerland) were selected. Teeth were standardized to a length of $15 \mathrm{~mm}$ from the apex by using an IsoMet 1000 precision saw (Buehler, Lake Bluff, IL, USA). Apical patency was determined by inserting a size $15 \mathrm{~K}$-file (Dentsply Maillefer) into the root canal until its tip was visible at the apical foramen under an operating microscope (DFV Comercial e Ind. Ltda, Valença, RJ, Brazil) at $20 \mathrm{X}$ magnification, and the working length (WL) was set $1 \mathrm{~mm}$ short of this measurement.

\section{Root Canal Preparation}

A single operator instrumented the canals of all specimens, using Reciproc ${ }^{\circledR}$ R25 single-files (25/0.08, VDW $\mathrm{GmbH}$, Munich, Germany), using RECIPROC ALL program (VDW). R25 files were used in a slow in-and-out pecking motion with a 3-mm amplitude limit combined with brushing motion. After 3 pecking motions, the file was withdrawn and then cleaned and inspected before being reused. The canal was rinsed with the irrigant substances, and a $15 \mathrm{~K}$-file was used to confirm patency. This procedure was repeated until the file reached the WL.

\section{Experimental Groups and Irrigation Protocol}

The samples were randomly divided into eight experimental groups $(n=10)$ using a computer algorithm (http://www.ramdom.org) according to the irrigation technique and irrigant substance: $\mathrm{G} 1(\mathrm{EV}+\mathrm{NaOCl}) ; \mathrm{G} 2$ $(\mathrm{EV}+\mathrm{CHXg}+\mathrm{SS}) ; \mathrm{G} 3(\mathrm{EV}+\mathrm{CHXs}) ; \mathrm{G} 4(\mathrm{EV}+\mathrm{SS}) ; \mathrm{G} 5(\mathrm{Cl}+$ $\mathrm{NaOCl}) ; \mathrm{G} 6(\mathrm{Cl}+\mathrm{CHXg}+\mathrm{SS}) ; \mathrm{G} 7(\mathrm{Cl}+\mathrm{CHXs}) ; \mathrm{G} 8(\mathrm{Cl}+\mathrm{SS})$

The total volume used was $10 \mathrm{~mL}$ for all groups, except for $\mathrm{G} 2$ and $\mathrm{G} 6$. For these groups the volume was $2 \mathrm{~mL}$ of $\mathrm{CHXg}$ and $8 \mathrm{~mL}$ of SS for volume standardization.

The 2\% CHX-gel (Endogel, Itapetininga, SP, Brazil) consisted of a gel base ( $1 \%$ natrosol) and $\mathrm{CHX}$ gluconate at $\mathrm{pH}$ 7.0. $\mathrm{NaOCl}$ was prepared by Drogal (Piracicaba, SP, Brazil).

EndoVac: Irrigant was delivered via the master delivery tip, and microcannula was used for evacuation of the solution. After every $6 \mathrm{~s}$, the microcannula was withdrawn 2 $\mathrm{mm}$ for $6 \mathrm{~s}$ to evacuate microtubules and insure a constant irrigant exchange, and then the microcannula was placed $1 \mathrm{~mm}$ short of WL. After each 3 pecking motions, the root canals were irrigated with the EndoVac for $1 \mathrm{~min}$ and following root canal preparation it was used for 2 min as a final rinse.

Needle: Irrigant was applied with a syringe and a 30-gauge needle (NaviTip, Ultradent Products Inc, South Jordan, UT, USA). The irrigation needle was placed as far into the canal as possible without binding and no longer than $1 \mathrm{~mm}$ from the WL. The evacuation of the irrigant solution was performed by using Capillary Tips $0.36 \mathrm{~mm}$ (Ultradent Products INC, South Jordan, UT, USA).

\section{Debris Collection}

The method used for the collection of apically extruded debris was adapted from a previous study (21).

Eppendorf tubes were weighted using a $10^{-5}$-g precision analytic microbalance (SP Labor, São Paulo, SP, Brazil). Three consecutive weights were obtained for each tube and mean was considered to be its initial weight. A 27-G needle was placed alongside the stopper to be used as a drainage cannula and to equalize the air pressure inside and outside the tubes. Next, each stopper with the tooth and the needle was attached to its Eppendorf tube, and the tubes were fitted into vials. The operator was shielded from seeing the root apex during the instrumentation procedures by a rubber dam that obscured the vial. Immediately after canal instrumentation, the Eppendorf tube was removed from the vial.

Each tooth was removed from the Eppendorf tube and the debris adhered to the root surface was collected by washing off the apex with $1 \mathrm{~mL}$ of distilled water into the Eppendorf tube. The tubes were stored in an incubator at $68^{\circ} \mathrm{C}$ for 5 days to evaporate the moisture before weighing the dry debris (22). Weighing was carried out again and three consecutive weights were obtained for each tube, and the mean was calculated. The dry weight of the extruded debris was calculated by subtracting the weight of the empty tube from that of the tube containing debris. 


\section{Statistical analysis}

As the preliminary analysis of the raw pooled data revealed a bell-shaped distribution (D'Agostino and Person omnibus normality test), statistical analysis was performed using analysis of variance ANOVA and post hoc Tukey test for multiple comparisons. The alpha-type error was set at 0.05 .

\section{Results}

All groups were associated with apical debris extrusion. $\mathrm{EV}$ was associated with less extruded debris when compared to $\mathrm{Cl}(\mathrm{p}<0.05)$ (Fig. 1). No differences were observed regarding the irrigant substance when $\mathrm{EV}$ was used during irrigation; however, when $\mathrm{Cl}$ was used, 2\% CHXg + SS was associated with lower debris extrusion than other irrigants $(p<0.05)$ (Fig. 2).

\section{Discussion}

To the best of the current authors' knowledge, this is the first study evaluating the influence of different irrigation techniques ( $\mathrm{EV}$ and $\mathrm{Cl}$ ) and irrigation substances $(\mathrm{NaOCl}, \mathrm{CHXg}+\mathrm{SS}, \mathrm{CHXs}$ and SS) on the amount of apically extruded debris.

The first part of the present study showed that irrespective the irrigant substance used, EV was associated with less debris extrusion than $\mathrm{Cl}$. Our results are in accordance with previous studies that evaluated debris extrusion and compared $\mathrm{EV}$ with $\mathrm{Cl}$ (10-12,23-25); however, it is the first time that EV is evaluated using chlorhexidine either in gel or in liquid presentation. The second part of the present study pointed-out an absence of differences on the extruded debris amongst the four different root canal irrigant when EV was used as irrigation technique. In contrast, when $\mathrm{Cl}$ was used, less debris extrusion was achieved by $2 \%$ $\mathrm{CHXg}+\mathrm{SS}$ group. The viscosity and rheological action of $\mathrm{CHX}$ gel, which keeps the debris in suspension (14), apparently minimizes the risk of debris extrusion, since statistically significant difference was observed in comparison with $6 \% \mathrm{NaOCl}, 2 \%$ CHX solution and SS. It is important to emphasize that in all canals the

Figure 1. Amount of apically extruded debris comparing the different irrigation systems. The bars represent the standard deviation (sd) and different letters represent statistically significant differences $(\mathrm{p}<0.05)$.

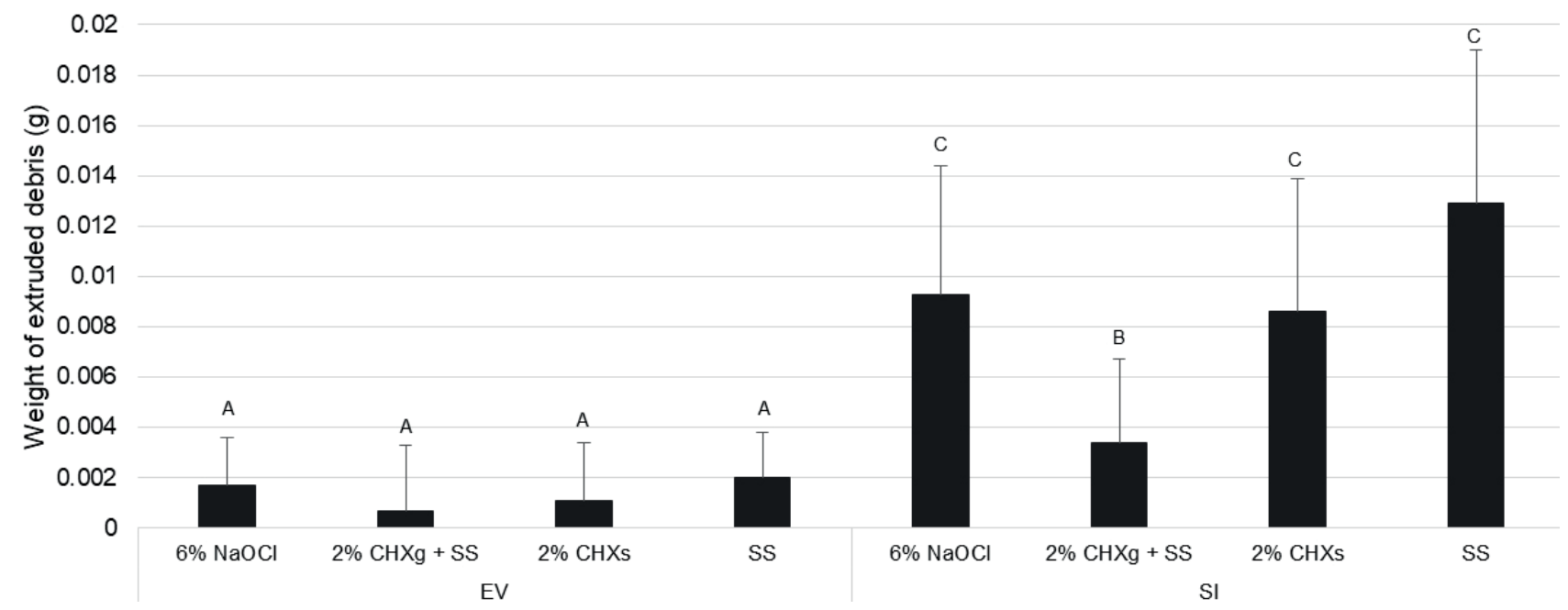

Figure 2. Amount of extruded debris comparing the different associations (irrigation technique and irrigant solution). The bars represent the standard deviation $(\mathrm{sd})$ and different letters represent statistically significant differences $(\mathrm{p}<0.05)$. 
same amount of irrigant was used during instrumentation. Therefore, the null hypothesis was rejected.

The well-stablished method described by Myers and Montgomery (21) was used in the present study, as recently recommended by Tanalp and Güngor (26), as the system that has received the most attention and has been adopted by most studies pertaining to apical extrusion of debris. However, it is worth mentioning that this experiment was conducted using extracted teeth with their apices suspended in air (zero back pressure); therefore, the periapical tissues were not mimicked. The results of the current study might be different if applied in a clinical situation in which the periapical tissues act as a natural barrier, which could limit apical debris extrusion (27). Also, the implications of a vital or necrotic pulp and the presence of a lesion of endodontic origin in the apical extrusion of debris are not clear.

In the present study, teeth were carefully selected according to tooth type, canal size at the working length, number of canals and canal curvature. This ensured that the apical extrusion of debris was due to the study variables (irrigation techniques and/or irrigant substance) and not due to tooth morphology. Mechanical preparation was performed by using reciprocating files, as they allow less debris extrusion than the conventional rotary systems (28), are simple, faster and as efficient technique as the multiple-file system (2).

One methodological aspect that should be discussed is that the experimental groups in this study differed not only in the mode of irrigant delivery (positive and negative pressure) and irrigant substances, but also in the delivery protocol, which was not possible to standardize. This issue has been recently pointed-out by Versiani et al. (29). This lack of standardization is a very common problem with studies using EndoVac system protocol, because the irrigant is not delivered within the root canal system, but in the pulp chamber. Thus, despite the reported results reflect true differences between the tested protocols, it remains unclear in which magnitude the difference in the irrigant delivery affected the results, and further studies are required.

Nowadays with the use of rotary instrumentation, high concentrated chemical substances for the chemomechanical preparation (e.g. $6 \% \mathrm{NaOCl}$ ) and the new concepts of working length closer to the apical foramen, it seems that the EndoVac system could be very helpful in decreasing the risk of flare-ups caused by the extrusion of irrigants.

It was concluded that no irrigation protocol succeeded in preventing debris extrusion. However, apical negative pressure irrigation (EV) resulted in lower levels of debris extrusion than conventional irrigation (CI). Moreover, during conventional irrigation, the use of $\mathrm{CHXg}+\mathrm{SS}$ resulted in lower debris extrusion.

\section{Resumo}

Este estudo avaliou a quantidade de debris extruidos apicalmente após o preparo químico-mecânico (PQM) utilizando sistemas de irrigação com pressão positiva e negativa [irrigação convencional (IC) e EndoVac (EV)] em associação com diferentes irrigantes [hipoclorito de sódio 6\% ( $\mathrm{NaOCI}$ ), clorexidina gel + solução salina (CLXg + SS), solução de clorexidina 2\% (CLXs) ou solução salina (SS)]. Oitenta pré-molares inferiores com único canal radicular foram selecionados e aleatoriamente alocados em 8 grupos $(n=10)$ de acordo com o sistema de irrigação e irrigante utilizado durante o PQM: G1 (EV + NaOCI), G2 (EV + CLXg + SS), G3 (EV + CLXs), G4 (EV + SS), G5 (IC + NaOCI), G6 (IC + CLXg + SS), G7 (IC + CLXs) e G8 (IC + SS). Limas Reciproc ${ }^{\circledR}$ R25 foram utilizadas durante o PQM e os debris extruídos de cada dente foi coletado em tubos pré-pesados e secos. 0 peso médio de debris foi avaliado por meio de microbalança, e os dados foram analisados estatisticamente utilizando ANOVA e teste de Tukey $(\alpha=0.05)$. Todos os grupos foram associados com extrusão de debris. EV foi o sistema de irrigação com menos debris extruídos ( $p<0.05)$. Não foram observadas diferenças entre os irrigantes quando o $\mathrm{EV}$ foi utilizado. Quando foi utilizada IC, CLXg + SS foram associados a menor extrusão de debris $(p<0.05)$. Concluiu-se que nenhum protocolo de irrigação conseguiu prevenir extrusão de debris. EV resultou em menores niveis de extrusão de debris que a IC. A utilização da CLXg + SS resultou em menor extrusão de debris.

\section{Acknowledgements}

This study was supported by Research Support Foundation of the State of São Paulo (FAPESP - 2012/23.697-4; 2015/23.479-5), National Scientific and Technological Development Council (CNPq - 308162/2014-5) and Coordination for Improvement of Higher Education Personnel (CAPES). We would like to thank Mr Maicon R Z Passini for technical support.

\section{References}

1. Desai $P$, Himel V. Comparative safety of various intracanal irrigation systems. J Endod 2009;35:545-549.

2. Bürklein $S$, Benten $S$, Schafer E. Quantitative evaluation of apically extruded debris with different single-file systems: Reciproc, F360 and OneShape versus Mtwo. Int Endod J 2014;47:405-409.

3. Farmakis ETR, Sotiropoulos GG, Abràmovitz I, Solomonov M. Apical debris extrusion associated with oval shaped canals: a comparative study of WaveOne vs Self-Adjusting File. Clin Oral Invest 2016;20:2131-2138.

4. Jamleh A, Fukumoto Y, Takatomo Y, Kobayashi C, Suda H, Adorno CG. A comparison between two negative pressure irrigation techniques in simulated immature tooth: an ex vivo study. Clin Oral Invest 2016;20:125-131.

5. Onay EO, Ungor M, Yazici AC. The evaluation of endodontic flareups and their relationship to various risk factors. BMC Oral Health $2015 ; 15: 142$.

6. Azim AA, Azim KA, Abbott PV. Prevalence of inter-appointment endodontic flare-ups and host-related factors. Clin Oral Investig 2017;21:889-894.

7. Nair M, Rahul J, Devadathan A, Mathew J. Incidence of Endodontic Flare-ups and Its Related Factors: A Retrospective Study. J Int Soc Prev Community Dent 2017;7:175-179.

8. Peters $0 A$. Current challenges and concepts in the preparation of root canal systems: a review. J Endod 2004;30:559-567.

9. Munoz HR, Camacho-Cuadra K. In vivo efficacy of three different endodontic irrigation systems for irrigant delivery to working length of mesial canals of mandibular molars. J Endod 2012;38:445-448.

10. Mitchell RP, Yang SE, Baumgartner JC. Comparison of apical extrusion of $\mathrm{NaOCl}$ using the EndoVac or needle irrigation of root canals. J Endod 2010;36:338-341.

11. Heilborn C, Reynolds K, Johnson JD, Cohenca N. Cleaning efficacy of an 
apical negative-pressure irrigation system at different exposure times. Quintessence Int 2010;41:759-767.

12. Mitchell RP, Baumgartner JC, Sedgley CM. Apical extrusion of sodium hypochlorite using different root canal irrigation systems. J Endod 2011;37:1677-1681.

13. Zehnder M. Root canal irrigants. J Endod 2006;32:389-398.

14. Gomes BPFA, Vianna ME, Zaia AA, Almeida JF, Souza-Filho FJ, Ferraz CC. Chlorhexidine in endodontics. Braz Dent J 2013;24:89-102.

15. Uezu MKN, Britto MLB, Nabeshima CK, Pallotta RC. Comparison of debris extruded apically and working time used by protaper universal rotary and protaper retreatment system during gutta-percha removal. J App Oral Sci 2010;18:542-545.

16. Deonizio MDA, Sydney GB, Batista A, Pontarolo R, Guimarães PRB, Gavini G. Influence of apical patency and cleaning of the apical foramen on periapical extrusion in retreatment. Braz Dent J 2013;24:482-486.

17. Costa EL, Sponchiado-Júnior EC, Garcia LFR, Marques AAF. Effect of large instrument use on shaping ability and debris extrusion of rotary and reciprocating systems. J Investig Clin Dent 2017;e12289.

18. Verma M, Meena N, Kumari RA, Mallandur S, Vikram R, Gowda V. Comparison of apical debris extrusion during root canal preparation using instrumentation techniques with two operating principles: An in vitro study. J Conserv Dent 2017;20:96-99.

19. De-Deus G, Brandão MC, Barino B, Di Giorgi K, Fidel RA, Luna AS. Assessment of apically extruded debris produced by the single-file ProTaper F2 technique under reciprocating movement. Oral Surg Oral Med Oral Pathol Oral Radiol Endod 2010;110:390-394.

20. Estrela C, Bueno MR, Sousa-Neto, Pécora JD. Method for determination of root curvature radius using cone-beam computed tomogragphy images. Braz Dent J 2008;19:114-118.

21. Myers GL, Montgomery S. A comparison of weights of debris extruded apically by conventional filing and canal master techniques. J Endod $1991 ; 17: 275-279$.
22. Ferraz CC, Gomes NV, Gomes BP, Zaia AA, Teixeira FB, Souza-Filho FJ. Apical extrusion of debris and irrigants using two hand and three engine-driven instrumentation techniques. Int Endod J 2001;34:354358.

23. Nielsen BA, Baumgartner J. Comparison of the EndoVac system to needle irrigation of root canals. J Endod 2007;33:611-615.

24. Gregorio C, Estevez R. Efficacy of different irrigation and activation systems on the penetration of sodium hypochlorite into simulated lateral canals and up to working length: an in vitro study. J Endod 2010;36:1216-1221.

25. Gade VJ, Sedani SK, Lokade JS, BelsareLD, Gade JR. Comparative evaluation of debris removal from root canal wall by using EndoVac and conventional needle irrigation: an in vitro study. Contemp Clin Dent 2013;4:432-436

26. Tanalp J, Güngör T. Apical extrusion of debris: a literature review of an inherent occurrence during root canal treatment. Int Endod J 2014:47:211-221.

27. Salzgeber RM, Brilliant JD. An in vivo evaluation of the penetration of an irrigating solution in root canals. J Endod 1977;3:394-398.

28. De-Deus G, Neves A, Silva EJ, Mendonça TA, Lourenço $C$, Calixto $C$, et al. Apically extruded dentin debris by reciprocating single-file and multi-file rotary system. Clin Oral Invest 2015;19:357-361.

29. Versiani MA, Alves FR, Andrade-Junior CV, Marceliano-Alves MF, Provenzano JC, Rôças IN, et al. Micro-CT evaluation of the efficacy of hard-tissue removal from the root canal and isthmus area by positive and negative pressure irrigation systems. Int Endod J 2015;49:10791087.

Received October 24, 2017 Accepted December 11, 2017 